\title{
PENERAPAN ASAS PEMISAHAN HORISONTAL DALAM PENYELESAIAN SENGKETA ANTARA PEMILIK TANAH DENGAN PEMILIK BENDA YANG ADA DI ATASNYA \\ (Studi Kasus Di Kecamatan Putri Betung Kabupaten Gayo Lues)
}

\author{
1Desi, ${ }^{2}$ Herinawati, ${ }^{2}$ Nasrianti \\ Email: desigayo36@gmail.com \\ ${ }^{1}$ Mahasiswa Fakultas Hukum UNiversitas MAlikussaleh \\ ${ }^{2}$ Dosen Fakultas Hukum Universitas Malikussaleh
}

\begin{abstract}
Abstrak
Asas pemisahan horisontal tersirat dalam Pasal 5 UUPA "Hukum agraria yang berlaku atas tanah, air dan ruang angkasa adalah hukum adat, sepanjang tidak bertentangan dengan kepentingan nasional dan negara, berdasarkan persatuan bangsa, dengan sosialisme Indonesia dan dengan peraturan yang tertuang dalam undang-undang ini serta peraturan perundang-undagan lainnya". Sedangkan dalam kasus di Kecamatan Putri Betung Kabupaten Gayo Lues dalam penyelesaian sengketa antara pemilik tanah dan pemilik benda yang ada di atasnya. Asas pemisahan horisontal belum diterapkan secara maksimal karena minimnya pengetahuan masyarakat tentang hal tersebut. Penelitian dalam studi ini dilakukan secara kualitatif dengan pendekatan yuridis sosiologis. Jenis penelitian merupakan penelitian deskriptif-analisis dengan menggunakan tipe penelitian lapangan, kegiatan lapangan dilakukan dengan melalui wawancara dan penelitian pustaka yang bertujuan untuk memberikan hasil analisa yang menyangkut objek yang diteliti berdasarkan hukum positif. penelitian ini menemukan hasil bahwa penerapan asas pemisahan horisontal di Kecamatan Putri Betung Kabupaten Gayo Lues tidak secara maksimal. Hambatan yang terjadi dalam penyelesaian sengketa adalah pihak bersengketa tidak menerima kesepakatan, adanya iktikad tidak baik, sulitnya menemukan saksi dan minimnya pengetahuan masyarakat mengenai kedudukan asas pemihan horisontal. Dan upaya yang dilakukan untuk mengatasi hambatan penyelesaian sengketa tersebut adalahpara pihak dipaksa tunduk dengan putusan yang ditetapkan oleh kepala desa, pendekatan secara personal dilakukan oleh kepala desa kepada pihak yang melekukan iktikad tidak baik, memanfaatkan masyarakat yang mengetahui permasalahan sebagai saksi, dan para pihak yang menyelesaiakan sengkata meskipun minimnya pengetahuanya mengenai asas pemisahan horisontal tersebut.
\end{abstract}

Kata kunci : Penerapan Asas Pemisahan Horisontal, Penyelesaian Sengketa Tanah 


\section{PENDAHULUAN}

Tanah merupakan kebutuhan hidup manusia yang sangat mendasar. Selain kebutuhan pokok pada umumnya tentang sandang dan pangan. Manusia hidup serta melakukan aktivitas di atas tanah sehingga setiap saat manusia selalu berhubungan dengan tanah dan dapat dikatakan hampir semua kegiatan hidup manusia baik secara langsung maupun tidak langsung selalu memerlukan tanah. ${ }^{1}$ Sengketa tanah adalah situasi dimana ada pihak yang merasa dirugikan oleh pihak lain, yang kemudian pihak tersebut menyampaikan ketidakpuasan ini kepada pihak kedua. Jika situasi menunjukkan perbedaan pendapat maka terjadilah yang dinamakan sengketa. ${ }^{2}$ Keberadaan Undang-Undang Nomor 5 Tahun 1960 tentang Peraturan Dasar UndangUndang Pokok Agraria (UUPA) sangatlah penting untuk memberikan kepastian hukum di bidang pertanahan. Karena sebelum berlakunya UUPA terdapat dualisme yang mengatur masalah pertanahan, yaitu hukum pertanahan berdasarkan pada hukum adat dan hukum pertanahan yang berdasarkan pada KUH Perdata. ${ }^{3}$ UUPA merupakan perwujudan upaya maksimal bangsa Indonesia untuk membebaskan diri dari ketergantungan dengan bangsa lain di bidang hukum pertanahan. ${ }^{4}$

Asas pelekatan yang dianut kolonial sangat bertentangan dengan hukum tanah adat dimana hukum tanah adat menganut azas pemisahan horisontal. Azas pemisahan horisontal yang dianut hukum tanah adat menyatakan bangunan, tanaman, dan benda-benda yang bersifat ekonomis lainnya yang ada di atas tanah bukanlah merupakan bagian dari tanah. Kata lain, kepemilikan atas tanah tidak meliputi kepemilikan atas bangunan di atasnya, bangunan berada di bawah kepemilikan pihak yang membangun bangunan tersebut. 5

Salah satu aspek yang penting di dalam hukum tanah adalah tentang hubungan hukum antara tanah dengan benda lain yang melekat padanya. Kepastian hukum akan kedudukan hukum dari benda yang melekat pada tanah itu sangat penting dan karena hal ini memiliki pengaruh yang luas terhadap segala hubungan hukum yang

\footnotetext{
${ }^{1}$ Susanti Ante, Penerapan Asas Pemishan Horisontal Terhadap Kepemilikan Hak Atas Tanah, Jurnal Elektronik Bagian Hukum Dan Masyarakat, Volume III, Nomor 6 Juli 2015, Unsrat, Manado, 2015, hlm. 79

${ }^{2}$ Ibid.

${ }^{3}$ Nasrullah, Analisis Hukum Se cara Secara Analogi Penerapan Asas Pemisahan Horizontal Pada Praktek Jual Beli Tidak Beserta Dengan Pohon Kelapa Tidak Diatasnya Di Kec. Patilanggo Kab. Pohuwato, Jurnal Hukum Volkgeist Memberi Pendidikan Hukum Nasional, Volume 2 Nomor 2 April 2018, Uig, Gorontalo, 2018, hlm 135-136.

4 Dyah Devina Maya Ginandra Dan Faizal Kurniawan, Kriteria Asas Pemisahan Horizontal Terhadap Penguasaan Tanah Dan Bangunan, Jurnal Yuridika, Volume 32 Nomor 2 Mei 2017, Universitas Airlangga, Surabaya, 2017, hlm. 229-230.

${ }^{5}$ Sukardi, Politik Hukum Terhadap Penggunaan Hak Atas Tanah Dan Bangunan Bagi Orang Asing Di Indonesia, Jurnal Yuridika, Xll. 1997.
} 
menyangkut tanah dan benda yang melekat padanya: ${ }^{6}$ UUPA menganut asas hukum adat karena itu juga menganut asas pemisahan horisontal hal mana tersirat dalam ketentuan Pasal 5 UUPA.

"Hukum agraria yang berlaku atas bumi, air, dan ruang agkasa ialah hukum adat, sepanjang tidak bertentangan dengan kepentingan nasional dan Negara, yang berdasarkan atas persatuan bangsa, dengan sosialisme Indonesia serta dengan peraturan-peraturan yang tercantum dalam undang-undang ini dan dengan peraturan perundangan lainnya, segala sesuatu dengan mengindahkan unsurunsur yang bersandar pada hukum agama."

Hukum tanah dikenal dua (2) asas yang satu sama lain bertentangan yaitu dikenal dengan asas pelekatan vertikal (vertical accessie baginsel) dan asas pemisahan horisontal (horizontale scheiding beginsel). Sejak berlakunya KUH Perdata kedua asas ini diterapkan secara berdampingan sesuai dengan tata hukum yang berlaku dewasa itu (masuk dualistis). Sejak berlakunya UUPA maka ketentuan Buku II KUH Perdata sepanjang mengenai bumi, air, serta kekayaan di dalammya telah dicabut, kecuali tentang hipotik. ${ }^{7}$ Asas pemisahan horisontal adalah asas dalam hukum Indonesia yang memisahkan kepemilikan tanah dengan kepemilikan atas benda-benda yang berada di atas atau di bawah permukaan tanah, misalnya bangunan, tumbuhan, minyak bumi, dan lain-lain. Dalam hukum Indonesia dimungkinkan pemilikan secara pribadi bagianbagian bangunan, karena hukum Indonesia menggunakan asas pemisahan horisontal, yaitu asas yang saat ini diberlakukan dalam Hukum Pertanahan Nasional, mengenyampingkan asas perlekatan yang telah dijelaskan sebelumnya. Dalam azas pemisahan horisontal, bangunan dan tanaman yang ada di atas tanah bukanlah merupakan bagian dari tanah sehingga kepemilikan bangunan dan tanaman yang terdapat di atas sebidang tanah tidak ikut serta jatuh kepada pemilik tanah. ${ }^{8}$ Azas pemisahan horisontal hak-hak atas tanah yang merupakan sifat asli hak-hak dalam hukum adat, tetap dipertahankan tetapi disesuaikan dengan kenyataan kebutuhan masyarakat masa kini.

Berkaitan dengan azas pemisahan horisontal, pada tahun 2016 sampai 2019 di dua kampung di Kecamtan Putri Betung terjadi tiga (3) kasus yaitu dua kasus yang terjadi di kampung Uning Pune dan satu kasus yang terjadi Kampung Gumpang. Dengan demikian, penelitian ini akan membahas 3 (tiga) kasus yang menyangkut azas pemisahan horisontal di Kecamatan Putri Betung, Kabupaten Gayo Lues. Berdasarkan uraian yang terdapat di atas, maka menjadi dasar untuk melakukan penelitian yang berjudul “Tinjauan Hukum Terhadap Penerapan Azas Pemisahan Horisontal Dalam

6 Cicilia Putri Andari Dan Djumadi Purwoatmodjo, Akibat Hukum Asas Pemisahan Horizontal Dalam Peralihan Hak Atas Tanah, Jurnal Notarius, Volume 12 Nomor 2, 2019, Universitas Diponegoro, Semarang, 2019, hlm. 712-713

${ }^{7}$ Noer Fauzi, Tanah Dan Pembangunan, Pustaka Sinar Harapan, Jakarta, 1997, hlm.30.

${ }^{8}$ Marihot Pahala Siahaan, Hukum Bangunan Gedung Di Indonesia, Rajawali Press, Jakarta, 1998. hlm.32. 
Penyelesaian Sengketa Antara Pemilik Tanah Dengan Pemilik Benda Yang Ada di Atasnya (Studi Penelitian di Kecamatan Putri Betung Kabupaten Gayo Lues").

\section{METODE PENELITIAN}

Jenis penelitian ini termasuk dalam jenis kualitatif yang akan menghasilkan data deskriptif mengenai permasalahan terkait. Jenis penelitian ini terkait dengan penerapan hukum azas pemisahan horisontal dalam penyelesaian sengketa antara pemilik tanah dan pemilik benda yang ada di atasnya Penelitian ini menggunakan pendekatan yuridis empiris yaitu suatu penelitian yang menekankan pada peraturan hukum yang berlaku dihubungkan dengan implementasinya dalam praktek diberlakukan di masyarakat Kecamatan Putri Betung Kabupaten Gayo Lues dengan penelitian di lapangan. Penelitian ini bersifat deskriftif analisis, yaitu menggambarkan, menelaah, menjelaskan secara tepat dengan teori-teori hukum dalam praktek pelaksanaan hukum positif sehubungan dengan masalah yang di teliti. ${ }^{9}$ Tanah dan benda yang ada di atasnya merupakan benda yang terpisah menurut azas pemisahan horisontal dan banyak yang terjadi berbedanya kepemilikan hak antara tanah dan benda yang ada di atasnya. Teknik pengumpulan data yang dilakukan dalam penulisan skripsi ini adalah penelitian lapangan (Field Research) dan penelitian kepustakaan (Library Research). Dalam Penelitian ini Alat yang digunakan untuk pengumpulan data yang digunakan dalam penelitian ini adalah hasil penelitian lapangan dan pedoman kepustakaan. Analisis data pada kegiatan yang dimulai dari kegiatan pengumpulan data. Adapun data yang diperoleh baik dari penelitian lapangan maupun studi dokumen adalah berdasarkan data primer yang diperoleh dari lapangan dan data sekunder yang ada kemudian dianalisis dengan menggunakan metode deskriptif kualitatif, yakni mendeskripsikan data yang diperoleh baik berupa kata-kata lisan atau tertulis dari pihak yang diwawancara.

\section{HASIL PENELITIAN DAN PEMBAHASAN}

Penerapan Azas Pemisahan Horisontal Dalam Penyelesaian Sengketa Antara Pemilik Tanah dan Pemilik Benda Yang Ada di Atasnya di Kecamatam Putri Betung Kabupaten Gayo Lues

Salah satu aspek yang penting di dalam hukum tanah adalah tentang hubungan hukum antara tanah dengan benda lain yang melekat padanya. Kepastian hukum akan kedudukan hukum dari benda yang melekat pada tanah itu sangat penting karena memiliki pengaruh yang luas segala hubungan hukum yang menyangkut tanah dan

\footnotetext{
${ }^{9}$ Ronny Hanittijo S, Metode Penelitian Hukum Dan Jeritmetri, Ghalia Indonesia, Bandung, 1994, hlm.97
} 
benda yang melekat padanya. ${ }^{10}$ Asas pemisahan horisontal hak-hak atas tanah yang merupakan sifat asli hak-hak dalam hukum adat, tetap dipertahankan tetapi disesuaikan dengan kenyataan kebutuhan masyarakat masa kini. Hak atas tanah tidak meliputi pemilikan atas bangunan yang ada di atasnya. Bangunan, tanaman, dan benda-benda lainya yang ada di atas suatu bidang tanah adalah milik pihak yang membangun atau yang menanam, baik itu pihak pemegang hak atas tanahnya sendiri atau bukan, kecuali kalau ada perjanjian sebaliknya. ${ }^{11}$ Suatu penyelesaian sengketa tanah dapat diselesaikan melalui pengadilan dan di luar pengadilan, salah satunya diselesaikan secara adat. Azas pemisahan horisontal adalah asas dalam hukum Indonesia yang memisahkan kepemilikan tanah dengan kepemilikan atas bendabenda yang berada di atas atau di bawah permukaan tanah, misalnya bangunan, tumbuhan, minyak bumi, dan lain-lain. Kecamatan Putri Betung belum diterapkan sepenuhnya azas pemisahan horisontal karena ketidak tahuan masyarakat tentang hal ini. Benda-benda yang ada di atas tanah tersebut kepimilikannya melekat pada tanah tersebut atau tidak terpisah. Setiap kasus sengkerta tanah yang ada di kampung tersebut diselesaikan melalui adat.12 Penerapan azas pemisahan horisontal adalah konsekuensi dari dimasukkannya unsur hukum adat ke dalam hukum pertanahan nasional. Dimana, azas pemisahan horisontal adalah kebalikan dari asas pelekatan yang mengatakan bangunan dan tanaman merupakan satu kesatuan dengan tanah atau tanah dan benda yang ada di atas maupun di dalam tanah tersebut tidak terpisah. Sebaliknya, azas pemisahan horisontal menyatakan bangunan dan tanaman bukan merupakan bagian dari tanah atau tanah dan benda-benda yang ada di atasnya merupakan suatu yang terpisah. Kecamatan Putri Betung merupakan salah satu kecamatan yang dibentuk Kabupaten Gayo Lues. Kecamatan ini dibentuk sesudah pemekaran Kabupaten Gayo Lues dari Kabupaten Aceh Tenggara di tahun 2002 dan memiliki luas daerah 516,38 Km. Kecamatan Putri Betung terdiri dari 10 Kampung Diantaranya Yaitu Kampung Kungke Jaya, Ramung Musara, Uning Pune, Gumpang Lempuh Pinanang Baris, Pumping Lempuh Paluh, Gumpang Pekan, Meloak Sepakat, Meloak Aih Ilang, Singah Mulo,dan Marpunge. ${ }^{13}$

Penelitian ini secara khusus dilakukan pada dua (2) kampung yaitu Kampung Uning Pune dan Kampung Gumpang Pekan di Kecamatan Putri Betung Kabupaten Gayo Lues. Kasus tentang tanah merupakan sengketa yang sering terjadi di dalam kehidupan bermasyarakat. Dalam kasus tanah, penerapan asas pemisahan horisontal

${ }^{10}$ Betty Rubiati, Yani Pujiwati Dan Muliani Djakaria, Asas Pemisahan Horizontal Dalam Kepemilikan Hak Atas Tanah Dan Bangunan Satuan Rumah Susun Bagi Masyarakat Berpenghasilan Rendah, Jurnal Sosiohumaniora, Volume 17 Nomor 2 Juli 2015, Universitas Padjajaran, Bandung, hlm.96

${ }^{11}$ Boedi Harsono, Menuju Penyempurnaan Hukum Tanah Nasional Dalam Hubungannya Dengan TAP MPR RI IX/2001, Penerbit Universitas Tri Sakti, Jakarta, 2003, hlm. 73.

${ }^{12}$ Madsah, Ketua Mukim Kecamatan Putri Betung, wawancara, Tanggal 04 November 2020

${ }^{13}$ Madsah, Ketua Mukim Kecamatan Putri Betung, Wawancara, Tanggal 04 November 2020 
sangat sering terjadi dalam lingkungan hidup masyarakat, namun begitu banyak pula masyarakat tidak paham dengan hal ini, bahwa kepemilikan hak atas tanah dapat berbeda dengan kepemilikan benda-benda yang ada di atasnya dan menjadi perselisihan diantara para pihak. Berikut ini akan dibahas 3 (tiga) kasus yang menyangkut azas pemisahan horisontal yang terjadi di Kecamatan Putri Betung, Kabupaten Gayo Lues:

Kasus yang pertama, pada tahun 2018 di Kampung Uning Pune, terjadi perselisihan antara Muhammad Ali atau pemilik benda dengan Samin atau pemilik tanah, pada saat itu pemilik tanah meminta pemilik benda untuk mengembalikan tanah tersebut, namun pemilik benda telah mendirikan rumah setengah permanen di atas tanah tersebut.14 Terjadi keributan diantara kedua belah pihak karena beberapa kali Muhammad Ali mendatangi Samin dikediamanya untuk merundingkan permasalahan ini supaya diselesaikan secara kekeluargaan namun Samin menolak permitaan Muhammad Ali tersebut karena pernah merasa sakit hati kepada Muhammad Ali karena masalah pribadi antara pemili tanah dengan pemilik benda, karena tidak mendapatkan solusi akhirnya Muhammad Ali mendatangi Pengulu Kampung Uning Pune untuk mengadukan masalah ini. ${ }^{15}$ Proses penyelesaian sengketa tanah tersebut para pihak dapat melaporkan langsung perkara mereka kepada Penghulu masing-masing kampung untuk dilakukan perundingan lalu diselesaikan di hadapan perangkat kampung seperti Pengulu, Kepala Dusun, dan perangkat lainnya yang dianggap ahli di bidangnya. Penyelesaian sengketa dilakukan dalam beberapa kali tahap pertemuan antara pemilk tanah dan pemilik benda serta para pihak yang ikut serta dalam penyelesaian sengketa ini. Musyawarah menghasilkan kesepakatan bahwa kasus sengketa ini akan diselesaikan secara adat sehingga pihak dari kasus pertama yaitu Muhammad Ali pemilik tanah dan Samin pemilik tanah sepakat untuk membeli rumah milik Muhammad Ali meskipun pada awalnya Samin keberatan dengan keputusan yang dijatuhkan oleh Pengulu tapi dengan perundingan yang cukup panjang akhirnya Samin menyetuinya juga. ${ }^{16}$ Pada kasus ini terjadi iktikad tidak baik yang dilakukan oleh Samin selaku pemilik tanah yang memaksa Muhammad Ali untuk menjual rumahnya dengan harga yang murah atau kurang wajar dari harga yang seharusnya, Muhammad Ali menerima karena tidak ingin memperpanjang perselisihan. ${ }^{17}$

Demikian, Penyelesaian sengketa ini menerapkan azas pemisahan horisontal karena hak atas tanah dan hak atas benda dipisahkan kepemilikannya. Putusan yang

\footnotetext{
${ }^{14}$ Rabi Thalib, Pengulu Kampung Uning Pune, Wawancara, Tanggal 25 Oktober 2020

${ }^{15}$ Samin, Pemilik Tanah, Wawancara, Tanggal 25 Oktober 2020

${ }^{16}$ Muhammad Ali, Pemilik Rumah/pemilik tidak sah tanah, Wawancara, Tanggal 25 Oktober 2020

17 Jubir, Saksi kasus pertama di Kampung Uning Pune, Wawancara, Tanggal 25 Oktober 2020
} 
di tetapkan oleh Pengulu (Kepala Desa) Muhammad Ali selaku pemilik benda menjual benda tersebut kepada Samin.

Kasus yang kedua sengketa tanah pada tahun 2016 di Kampung Uning Pune terjadi perselisihan antara pemilik tanah dan pemakai tanah yang sebelumnya telah membuat sebuah perjanjian pemilik tanah akan memberikan sebidang tanah lahan untuk bercocok tanam kepada pemakai tanah, namun beberapa tahun kemudian tepatnya di tahun 2016 setelah perjanjian tersebut dibuat pemilik tanah meminta kembali tanah tersebut untuk dikembalikan karena pemakai tanah tidak menggunakan tanah sesuai dengan perjanjian, sementara pemakai tanah telah menanam dua jenis tanaman yaitu tanaman kemiri dan tanaman coklat. Aliasan beberapa kali mendatangi kediaman Maddin untuk merundingkan masalah ini bahkan Aliasan telah memberikan peringatan kepada Maddin supaya Maddin segera membersihkan kebun tersebut namun tidak direspon olehnya. Karena tidak mendapatkan titik temu dalam beberapa pertemuan antara kedua belah pihak, Aliasan membawa masalah ini terlebih dahulu kepada Kepala Dusun Kampung Uning Pune terlebih dahulu. ${ }^{18}$ Maddin mengatakan pada saat Aliasan mendatanginya beberapa kali Maddin awalnya memang tidak merespon karena beberapa hal yang tidak dapat Maddin ceritakan namun saat kedatangan Aliasan terakhir kalinya Maddin berniat untuk segera memenuhi peringatan yang diberikan Aliasan untuk membersihkan kebunnya tapi sudah terlambat karena Aliasan sudah mengadukan masalah ini pada Kepala Dusun Kampung Uning Pune dan Aliasan tetap meminta Kepala Dusun mencarikan solusi untuk permasalahan ini. ${ }^{19}$ Dalam musyawarah untuk kasus sengketa yang kedua kedua belah pihak sepakat untuk menyelesaikan perselisihan secara adat yaitu Aliasan dan Maddin, sepakat untuk membagi dua bagian dari tanah dan tanaman yang telah ditaman oleh Maddin dalam perundingan yang tidak terlalu rumit sehingga dengan mudah mendapatkan titik temu karena kedua belah pihak tidak mau saling merugikan. ${ }^{20}$

Demikian penyelesaian sengketa antara pemilik tanah dan pemilik benda yang ada di atasnya, dalam penyelesaian sengketa ini tidak diterapkan azas pemisahan horisontal karena kedua belah pihak membagi bagian dari tanah dan juga benda untuk dimiliki oleh kedua belah pihak yang bersengketa tersebut.

Kasus yang ketiga pada tahun 2019 telah terjadi perselisihan antara pemilik tanah dan pemakai tanah, pemilik tanah meminta tanah yang dipakai oleh pemakai tanah yang dijadikan kios oleh pemakai tanah tersebut. Jadi sengketa tanah yang terjadi di kampung uning pune ini bukanlah yang pertama yang diselesaikan melalui peradilan adat. Bahkan kasus-kasus yang sebelumnya dapat diselesaikan secara

\footnotetext{
${ }^{18}$ Syaripudin, Kepala Dusun Kampung Uning Pune, Wawancara, Tanggal 26 Oktober 2020

${ }^{19}$ Maddin, Pemakai Tanah/Pemilik Tidak Sah Tanah, Wawancara, Tanggal 26 Oktober 2020

${ }^{20}$ Amiruddin, saksi kasus kedua Kampung Uning Pune, Wawancara, Tanggal 26 Oktober 2020
} 
damai melalui musyawarah. ${ }^{21}$ Dalam musyawarah untuk kasus sengketa yang ketiga kedua belah pihak juga sepakat untuk menyelesaikan perkaranya melalui adat yaitu Rajawali sebagai pemilik sah tanah dan Arwin sebagai pemakai tanah atau pemilik tanah tidak sah. Keduanya sepakat tidak ada yang berubah, tanah tetap menjadi milik Rajawali sedangkan Arwin tetap bisa membuka usaha kios tersebut. ${ }^{22}$ Arwin selaku pemilik benda mengaku tidak mengetahui bahwa Rajawali adalah pemilik sah dari tanah yang didirikannya sebuah kios tersebut karena sudah lama tanah tersebut tidak digunakan dan tetap berada didepan rumahnya Arwin, Arwin marah karena pada saat Arwin mendirikan kios tersebut tidak dilarang oleh Rajawali selaku pemilik sah namun Rajawali mempermasalahkan saat kios itu sudah siap untuk digunakan oleh Arwin. ${ }^{23}$ Meskipun sempat terjadi pertengkaran antara kedua belah pihak karena Arwin selaku pemakai tanah mengatakan tanah tersebut adalah milik keluarganya, namun surat-surat tanah tersebut ada di tangan Rajawali selaku pemilik sah tanah tersebut. Setelah Rajawali dapat membuktikan bahwa tanah itu adalah miliknya maka Arwin selaku pemakai tidak dapat membantah lagi. Pengulu Kampung Gumpang memberikan solusi untuk kedua belah pihak agar tidak ada yang dirugikan dalam kasus ini, maka Arwin boleh menggunakan kios tersebut di atas tanah Rajawali pun menyetuinya. ${ }^{24}$

Demikian penyelesaian sengketa antara pemilik tanah dan pemilik benda yang ada di atasnya, dalam penyelesaian sengketa tersebut sudad diterapkan azas pemisahan horisontal, hasil putusan yang ditetapkan adalah memperjelas kepemilikan hak atas tanah tersebut yaitu milik Rajawali.

\section{Hambatan Dalam Penyelesaian Sengketa Antara Pemilik Tanah Dengan Pemilik Benda-Benda Yang Ada Di Atasnya di Kecamatan Putri Betung Kabupaten Gayo Lues}

Dalam menyelesaikan perselisihan atau sengketa tentunya memiliki rintangan dan kesulitan untuk menemukan titik temu penyelesaian sengketanya sehingga dalam melakukan musyawarah terdapat beberapa hambatan dalam penyelesaian sengketa, termasuk juga dalam penyelesaian sengketa tanah di Kecamatan Putri Betung, diantaranya :

1. Para Pihak yang bersengketa tidak menerima hasil kesepakatan.

Para pihak yang bersengketa sebagian ada yang tidak menerima hasil dari kesepakatan, sehingga Para pihak yang menyelesaikan sengketa menjadi tidak

\footnotetext{
${ }^{21}$ Ikhwan Sabri, Pengulu Kampung Gumpang, Wawancara, Tanggal 30 Oktober 2020

22 Rajawali, Pemilik Sah Tanah, Wawancara, Tanggal 30 Oktober 2020

${ }^{23}$ Arwin, Pemakai Tanah/Pemilik Tidak Sah Tanah, Wawancara, Tanggal 30 Oktober 2020

${ }^{24}$ Sukrianto, Saksi Pada Kasus Ketiga Di Kampung Gumpang, Wawancara, Tanggal 30 Oktober
} 
terlalu serius dalam kasus ini. Pengulu Kampung Gumpang menyatakan bahwa pada awal perkara Pengulu mencoba mencari titik terang agar sengketa ini dapat diselesaikan dengan baik dan tidak ada pihak yang dirugikan, kalaupun ada, maka Pengulu mencari solusi agar tidak terlalu banyak pihak yang mengalami kerugian. Namun pihak pemilik tanah menolak solusi yang diberikan oleh Pengulu tersebut sehingga para pihak yang ikut menyelesaikan masalah ini tidak terlalu serius lagi. 25

2. Adanya itikad tidak baik dari salah satu pihak.

Para pihak dari kasus pertama, samin melakukan pemaksaan sehingga membuat pihak yang satu lagi menjadi rugi. ${ }^{26}$

3. Sulitnya menemukan saksi-saksi.

Dalam melakukan pembuktian terhadap status kepemilikan rumah milik Muhammad Ali, mengalami kesulitan mencari saksi karena sebagian pemilik rumah yang berbatasan sudah meninggal pada saat sengketa itu terjadi dan sebahagian saksi yang lain tidak bersedia membantu pemilik rumah tersebut karena saksi itu mengatakan tidak mau tahu tentang permasalahan yang sedang dihadapi oleh kedua belah pihak, sementara pemakai tanah sangat membtuhkan kesaksian dari saksi itu. ${ }^{27}$

4. Kurangnya pengetahuan masyarakat mengenai penyelesaian sengketa. Kurangnya pengetahuan masyarakat mengenai penyelesaian sengketa sehingga para pihak dalam menyelesaikan kasusnya sulit untuk menemukan titik terang. Masyarakat tidak mengetahui kedudukan asas pemisahan horisontal dalam penyelesaian sengketa ini, meskipun sudah diterapkan asas pemisahan horisontal tersebut, namun bukan atas dasar pengetahuan bahwa asas pemisahan horisontal memisahkan antara tanah dan benda-benda yang ada di atasnya dan pada saat penyelesaian sengketa belum ada pihak khusus yang menyelesaikan sengketa ini. 28

Upaya Yang Dilakukan Terhadap Penyelesaian Sengketa Antara Pemilik Tanah Dengan Pemilik Benda-Benda Yang Ada Di Atasnya Di Kecamatan Putri Betung Kabupaten Gayo Lues

Upaya yang dilakukan untuk mengatasi hambatan penyelesaian sengketa kasus yang pertama yaitu

\footnotetext{
${ }^{25}$ Ikhwan Sabri, Pengulu Kampung Gumpang, Wawancara, Tanggal 30 Oktober 2020

${ }^{26}$ Rabi Thalib, Pengulu Kampung Uning Pune, Wawancara, Tanggal 25 Oktober 2020

${ }^{27}$ Muhammad Ali, Pemilik Rumah/pemilik tidak sah tanah, Wawancara, Tanggal 25 Oktober 2020

${ }^{28}$ Madsah, Ketua Mukim Kecamatan Putri Betung, wawancara, Tanggal 04 November 2020
} 
1. Upaya yang dilakukan untuk megatasi hambatan para pihak tidak menerima kesepakatan adalah dalam beberapa kali pertemuan musyawarah, para pihak diwajibkan tunduk pada putusan yang ditetapkan oleh Pengulu (Kepala Desa) Uning Pune Kecamatan Putri Betung. ${ }^{29}$ Pengulu (Kepala desa) memutuskan salah satu pihak menjual tanah ataupun benda kepada salah satu pihak yang bersengketa untuk mempermudah penyelesaian.

2. Upaya yang dilakukan untuk mengatasi hambatan adanya iktikad tidak baik dari salah satu pihak yang bersengketa adalah dengan pendekatan personal yang dilakukan oleh Pengulu (kepala desa) kepada pihak (Samin) yang melakukan iktikad tidak baik tersebut, Pengulu meyakinkan bahwa tindakanya akan sangat merugikan pihak lain yang bersengketa denganya. Samin menyetujui untuk membeli rumah milik Muhammad Ali dengan syarat harga ditentukan oleh Samin. ${ }^{30}$

3. Uapaya yang dilakukan untuk mengatasi hambatan menemukan saksi adalah dengan menjadikan masyarakat yang mengetahui permasalah yang terjadi diantara pemilik tanah dan pemilik benda tersebut. Dalam pertama pertemuan antara pemilik tanah dan pemilik benda serta para pihak yang ikut serta dalam menyelesaikan sengketa tidak menemukan saksi karena saksi ada yang sudah meninggal dunia dan saksi lain tidak bersedia memberikan kesaksiannya untuk sengketa tersebut. Dipertemuan berikutnya pemilik benda membawa saksi yang mengetahui segala permasalah tersebut. ${ }^{31}$

4. Upaya yang dilakukan untuk mengatasi hambatan Kurangnya pengetahuan masyarakat dalam penyelesaian sengketa, para pihak yang ikut menyelesaian sengketa tersebut berupaya menemukan titik temu dengan peraturan adat yang ada. ${ }^{32}$ Meskupun kurangnya pengetahuan masyarakat tentang kedudukan UUPA dalam hukum pertanahan, namun para pihak yang menyelesaiakan sengketa ini berusaha menemukan penyelesaian agar tidak ada pihak yang dirugikan atau memenimalisir kerugaian yang akan di timbulakan akibat putusan yang ditetapkan. ${ }^{33}$

Demikian upaya yang dilakukan untuk mengatasi hambatan penyelesaian sengketa melalui musyawarah. Penerapan asas pemisahan horisontal di Kecamatan Putri Betung Kabupaten Gayo Lues tidak efektif atau tidak pakai lebih tepatnya masyarakat di Kecamatan Putri Betung tidak mengerti bahwa penerapan asas

\footnotetext{
${ }^{29}$ Rabi Thalib, Pengulu Kampung Uning Pune, Wawancara, Tanggal 25 Oktober 2020

${ }^{30}$ Muhammad Ali, Pemilik Rumah/pemilik tidak sah tanah, Wawancara, Tanggal 25

${ }^{31}$ Ikhwan Sabri, Pengulu Kampung Gumpang, Wawancara, Tanggal 30 Oktober 2020

${ }^{32}$ Syaripudin, Kepala Dusun Kampung Uning Pune, Wawancara, Tanggal 26 Oktober 2020

33 Rabi Thalib, Pengulu Kampung Uning Pune, Wawancara, Tanggal 25 Oktober 2020
} 
pemisahan horisontal dapat memisahkan kepemilikan atas tanah dan benda-benda yang terdapat di atas tanah tersebut.

\section{Kesimpulan}

Berdasarkan uraian pada bab-bab sebelumnya, maka dapat ditarik kesimpulan sebagai berikut:

1. Penerapan azas pemisahan horisontal dalam penyelesaian sengkata antara pemilik tanah dan pemilik benda yang ada di atasnya di Kecamatan Putri Betung Kabupaten Gayo Lues tidak secara maksimal dimana para pihak pemilik tanah maupun pemilik benda dan para pihak yang ikut serta dalam penyelesaian sengketa ini kurangnya pengetahuan tentang kedudukan azas pemihasan horisontaldalam hukum pertanahan

2. Hambatan dalam penyelesaian sengketa antara pemilik tanah dan benda-benda yang ada di atasnya adalah para pihak tidak menerima putusan, adanya iktikad tidak baik dari salah satu pemilik tanah, sulitnya menemukan saksi-saksi yang berbatasan dengan tanah tersebut dan kurangnya pengetahuan masyarakat mengenai azas pemisahan horisontal dapat memisahkan antara tanah dan benda yang ada di atas tanah tersebut dan tidak ada pihak kusus yang menangani permasalahan.

3. Upaya yang dilakukan terhadap hambatan dalam penyelesaian sengketa tanah dan pemilik benda-benda yang ada di atasnya ialah dengan para pihak dipaksa tunduk dengan putusan yang ditetapkan oleh kepala desa, pendekatan secara personal dilakukan oleh kepala desa kepada pihak yang melekukan iktikad tidak baik, memanfaatkan masyarakat yang mengetahui permasalahan sebagai saksi, dan para pihak yang menyelesaiakan sengkata meskipun minimnya pengetahuanya mengenai asas pemisahan horisontal tersebut.

\section{Saran}

1. Kepada pemilik benda seharusnya mempertimbangkan terlebih dahulu untuk mendirikan bangunan ataupu tananaman di atas tanah milik orang lain. Dibuat perjanjian tertulis agar pemakai tanah tidak dirugikan dan untuk

2. Kepada pemilik tanah harsunya bersikaplah bijaksana agar tidak ada yang dirugikan dalam perselisihan yang terjadi antara pemilik tanah dan benda-benda yang ada di atasnya.

3. Kepada Pengulu (kepala desa) seharusnya menyediakan pihak khusus yang memiliki pengetahuan mengenai sengekata yang serupa yang dapat tejadi di kemudian hari, Sangat diperlukan pihak khusus untuk mengatasi masalah yang 
terjadi agar keadilan benar-benar ada untuk semua orang dan masyarakat mendapatkan apa yang seharusnya didapatkan.

\section{DAFTAR PUSTAKA}

A Michael Huberman, 2007, Analisis Data Kualitatif, Universitas Indonesia Press, Jakarta.

Amiruddin dan Zainal Asikin, 2010, Pengantar Metode Penelitian Hukum, Rajawali Pers, Jakarta.

Betty Rubiati, Yani Pujiwati Dan Muliani Djakaria, 2015, Azas Pemisahan Horizontal Dalam Kepemilikan Hak Atas Tanah Dan Bangunan Satuan Rumah Susun Bagi Masyarakat Berpenghasilan Rendah, Jurnal Susiohumaniora, Volume 17 Nomor 2 Juli 2015, Universitas Padjajaran, Bandung

Boedi Harsono, 2003, Menuju Penyempurnaan Hukum Tanah Nasional Dalam Hubungannya Dengan TAP MPR RI IX/2001, Penerbit Universitas Tri Sakti, Jakarta.

Boedi Harsono, 2006, Hukum Agraria Indonesia Himpuanan Peratura-Peraturan Hukum Tanah, CV. Tarunagrafika, Jakarta. Dyah Devina, 2017, Kriteria Azas Pemisahan Horizontal Terhadap Penguasaan Tanah dan Bangunan, Jurnal Yuridika, Universitas Airlangga, Surabaya.

Burhan Bungin, 2002, Metodelogi PenelitiaN Sosial, Format-Format Kuantitatif Dan Kualitatif, Surabaya, Airlangga Press.

Cicilia Putri Andari Dan Djumadi Purwoatmodjo, 2019, Akibat Hukum Azas Pemisahan Horizontal Dalam Peralihan Hak Atas Tanah, Jurnal Notarius, Volume 12 Nomor 2 2019, Universitas Diponegoro, Semarang.

Christine Eka Herawati, 1994, Kasus Tanah Desa Yang Habis Masa Sewanya Sehubungan Dengan Azas Pemisahan Horizontal Menurut Hukum Adat, Skripsi, Fakultas Hukum Universitas Airlangga, Surabaya.

Dyah Devina, 2017, Kriteria Azas Pemisahan Horizontal Terhadap Penguasaan Tanah dan Bangunan, Jurnal Yuridika, Universitas Airlangga, Surabaya.

Eddy Ruchiyat, 2006, Politik Pertanahan Nasional Sampai Orde Repormasi, P.T. Alumni, Bandung.

Elita Hafizah, 1982, Sedikit Tinjauan Tentang Azas Pemisahan Horisontal Yang Dianit UUPA Serta Permasalahannya, Skripsi, Fakultas Hukum Universitas Airlangga, Surabaya.

Kartini Muljadi Dan Gunawan Widjaja, 2007, Seri Hukum Kekayaan Hak-Hak Atas Tanah, Prenada Media Grup, Jakarta.

Marihot P Siahaan, 2005, Bea Perolehan Hak Atas Tanah Dan Bangunan, PT Raja Grafindo Persada, Jakarta.

Nasrun Hipan, Nirwan Moh Nur, Hardianto Djanggih, 2018, Problematika Penyelesaian Sengkata Tanah Dilokasi Tanjung Sari Kabupaten Banggai, Jurnal Law Reform, Volume 14 Nomor 2 Tahun 2018, Universitas Diponegoro, Sulawesi Tengah. 
Nasrullah, 2018, Analisis Hukum Secara Analogi Penerapan Asas Pemisahan Horisontal Pada Praktek Jual Beli Tidak Beserta Dengan Pohon Kelapa yang di atasnya Di Kec. Patilanggo Kab. Pohuwato, Jurnal Hukum Volkgeist Member Pendidikan Hukum Nasional, UIG, Gorontalo.

Noer Fauzi, 1997, Tanah Dan Bangunan, Pustaka Sinar Harapan, Indonesia.

Prodjodikoro, Wirjono, 1986, Hukum Perdata Tentang Hak Atas Benda, Intermasa, Jakarta.

Rahmat Ramadhani, 2018, Kontruksi Hukum Kepemilikan Bangunan Di Atas

Rusmadi Usman, 2003, Pilihan Penyelesaian Sengketa Di Luar Pengadilan, PT. Citra Aditya Bakti, Bandung.

Ronny Hanitijo S,1994, Meteologi Penelitian Hukum Dan Jurimetri, Ghalia Indonesia, Bandung.

Saleh, K. Wantjik, 1982, Hak Atas Tanah, Ghalia Indonesia, Jakarta.

Zainuddin Ali, 2009, Metode Penelitian Hukum, Sinar Grafika, Jakarta. 